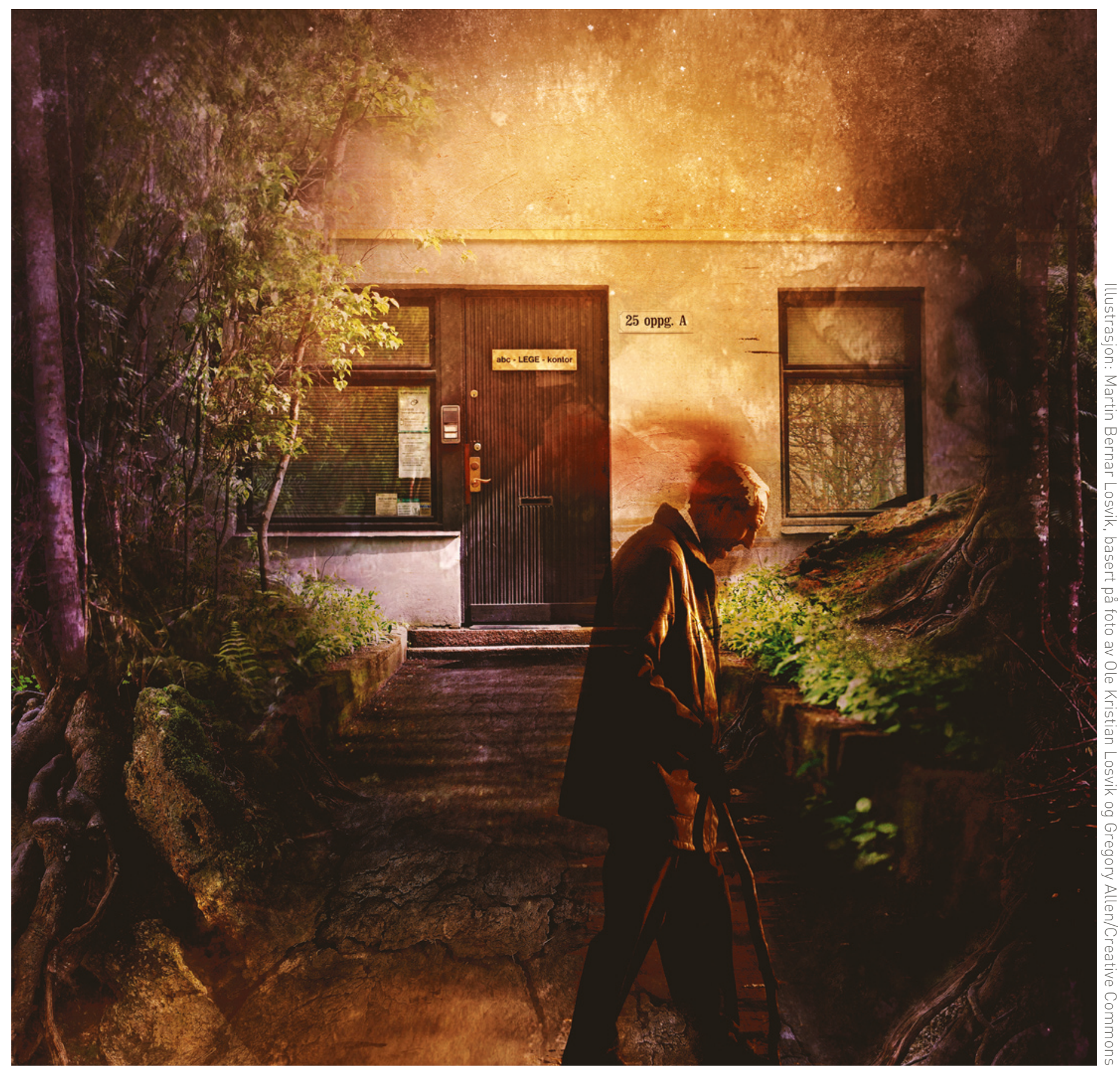

\title{
ABC Legesenter Majorstuen
}

1.2 Legesenteret ligger rett ved Sorgenfrigata på Majorstuen i Oslo. Det drives som solopraksis, noe som
gjelder ca. 30 \% av fastlegekontorene i landet, ifølge Legeforeningens fastlegestatistikk. 